\title{
Muslim scholars and the world of social media: opportunities and challenges
}

\author{
Muhammad Maga Sule ${ }^{1 *}$, Lawal Abdulkareem ${ }^{2}$ \\ 1,2 Usmanu Danfodiyo University, Sokoto
}

\begin{abstract}
The paper has examines what is considered dual contributions of the internet based medium of communication in da'wah. These platforms for social interaction and communication have become medium of spreading Islamic messages by Islamic scholars. The objective of the paper is to analyze how internet related mane of communications and interaction have aided da'wah. The researchers adopted an explanatory type of research whose aim is to explain a phenomenon of choice. The researchers sourced data from the secondary sources and analyzed them. It is on the basis of such that, the findings of this research have portrayed that social media as medium of social interaction have been adopted as tools for da'wah which learned Islamic scholars are using to propagate Islam and its teachings. However, the outcomes confirmed that social media have provided a fruitful ground for the germination of cyber space Islamic scholars, people who are not learned but share texts, video and audio containing distorted and misleading information. This has challenged the age long Islamic practice in Islam where any issues regarding Islamic da'wah and fatwa are exclusively for the learned Islamic Scholars. The study in addition reveal that what is obtainable on the social media now is, cyber scholars and quick to post or comment on issues that are exclusive the purview of Islamic scholars.
\end{abstract}

Keyword: challenges, interaction, muslim clerics, opportunities, social media

\begin{abstract}
Abstrak: Artikel ini telah meneliti apa yang dianggap sebagai kontribusi ganda dari media komunikasi berbasis internet dalam dakwah. Platform interaksi sosial dan komunikasi ini telah menjadi media penyebaran pesan-pesan Islam oleh para ulama. Tujuan dari makalah ini adalah untuk menganalisis bagaimana perilaku komunikasi dan interaksi terkait internet telah membantu dakwah. Para peneliti mengambil data dari sumber sekunder dan menganalisisnya. Atas dasar itulah, temuan penelitian ini menggambarkan media modern interaksi sosial telah diadopsi sebagai alat dakwah yang digunakan oleh para ulama terpelajar untuk menyebarkan Islam dan ajaran sunnah. Namun, hasil tersebut menegaskan bahwa media sosial telah memberikan landasan yang bermanfaat bagi perkecambahan cendekiawan Islam ruang cyber, orang-orang yang tidak terpelajar tetapi berbagi teks, video, dan audio yang berisi informasi yang menyimpang dan menyesatkan. Hal ini telah menantang praktik Islam yang sudah berlangsung lama dalam Islam di mana setiap masalah tentang dakwah dan fatwa Islam hanya ditujukan untuk para Cendekiawan Islam yang terpelajar. Studi tersebut juga mengungkapkan bahwa apa yang tersedia di media sosial saat ini adalah, cendekiawan dunia maya dengan cepat memposting atau mengomentari isu-isu yang merupakan bidang eksklusif ulama.
\end{abstract}

Kata Kunci: interaksi, media sosial, peluang, ulama, tantangan.

"Corresponding Author: : Muhammad Maga Sule | mailto:mohammed.maga@yahoo.com | Department of Islamic Studies, Usmanu Danfodiyo University, Sokoto, Nigeria 


\section{Introduction}

In modern ages, communications between individuals have entirely transformed with the appearance and development of computers and networks. Social relationships are going to start at the beginning of the web. People communicate, build relationships using social networks (Bandura, 1986). Today, social media adoption and use in a wide range of in every section human life. Muslims are not different from other societies, in the last few years, which has increased the use of social media trends. It has brought changes that can have a significant impact on the individual and group level of Muslim society. Social media is easy to use, easy to learn, and the ability to communicate public universality of speed (Habib, 2018). They have become tools which eased communication among or between human beings. In this era, the society is like techno-centrism whose value system is centered more on technology. They have absolute faith in technology and manipulate over nature (Saifuddeen \& Salleh, 2013). Nowadays, platforms for social interaction over the internet called social media could be considered as the main resource for sourcing and disseminating different kind of information. Every Muslim that believes in Allah knows the attainment in Information Communication Technology (ICT) is one indication of success that needs to be utilize in order in a search for authentic information and to find the truth (Jusoh, \& Kamaruzaman, 2009). People are encouraged to find the creation sign of Allah through any medium that is available in this day and age of digital technology (Jusoh, \& Kamaruzaman, 2009). Nothing impossible in seeking is knowledge, especially in today's world. As Allah has mentioned in the Glorious Qur'an;

We will show them Our signs in the horizons and within themselves until it becomes clear to them that it is the truth. But is it not enough concerning your Lord that $\mathrm{He}$ is, over all things, a Witness (Qur'an, Suratul Fussilat 41:53).

Allah created and fashioned man with the basic features to communicate. That is why Allah states in the Glorious Qur'an;

He has taught man the mode of expression (Qur'an, Sura ArRahmaan 55:4).

Social media platforms ought to become a medium for exchange of correspondence with Maqasid alShari'ah (course of Shari'ah), and it is regarded as daruriyyat which means the essential, necessities, and vital in fulfilling some basic needs of every human being on earth and after death (Aznan, 2012). In carrying out some Islamic obligations, Saidin (2012) states that social media could be used to disseminate Islamic messages and information to believers and unbelievers within a short time and cheaply compared to other traditional mass media.

Social media is an interactive medium or sites that permit users to interrelate between and among them. The mediums also enable the user to generate content, send and receive feedbacks from and to each other generally by means of the internet. They 
are medium which allow users to meet online via the internet, communicate in social forum like Facebook, twitter and other chat sites, where users usually socialise through sharing news, photographs or thoughts and ideas, or reply to issues and other contents with other individuals. A good examples these social media are the popular networking sites like Facebook, MySpace, YouTube, Flicker, Bebo, Wechat, Badoo and Google+. Social Media could be regarded as convergence of computer connected with internet which facilitate human interrelation, collaboration, deliberation among people regardless of physical boundary. The new internet aided medium for communication and interrelationship comprise but not limited to blogs, wikis, media (audio, photo, video, text) sharing tools, networking platforms (including Facebook), and virtual worlds (Sanusi, Gambo and Bashir, 2014).

\section{Methodology}

Exploratory research design is adopted for this paper because the aim of the research is to explore how social media platforms aid the spread of Islamic knowledge and the challenges faced. The study also aimed at understanding the opportunities and the challenges Muslim scholars encountered at the course of Da'wah and the Muslims scholars were the main subject of the research. The data were together from secondary source for the study. The researcher sourced data from documented texts generated from different social media sites and platforms to spread Islam. This is because of the increase interest by Islamic scholars in Nigeria to adopt the use of the social media as a means of communication to reach their audience. The use of secondary data in a research was pioneered by Glaser (1963). He submits that secondary analysis carried out by an independent researcher could, amongst other things, 'lend new strength to the body of fundamental knowledge of human beings. Different studies have shown that secondary analysis of data has been an old practice in the fields of social sciences and humanities disciplines where data are analyzed with a different purpose(s) other than what motivated the original researcher(s) to collect the data (Hinds, Vogel. and Clarke-Steffen, 1997). It is a normal practice in social research to undertake or analyzed an existing data for a different purpose or objective as the case maybe. (Hinds, Vogel, \& Clarke-Steffen, 1997; Heaton, 1998). The use of secondary data is often motivated by a desire to adopt a fresh perspective or a new theoretical framework other than the original research orientation and objectives (Heaton, 1998). The researcher therefore, sourced secondary data and analyzed them and found how Muslim scholars across different Muslim communities in the world adopt different social media site for the spread of Islam.

\section{Lierature review}

Theorizing social media

Social media could be regarded as a phrase, to examine every word individually. Social means a way of engaging other in an interactive form by sharing information with them and obtaining information from them. Media means communication device, such as the Internet (TV, radio, and newspaper 
media are examples of more traditional types). It could be deduced from the two word; a compound word can be derived to give a sound definition. Social media could be defined as a web-based communication tool that enables the sharing of both sharing and eating information with each other (Nations, 2019). Social media is a website or application that allows people to share their content very quickly and efficiently and as a means of communicating with people you know or strangers. Social media also means "Internet-based application on constructed Web 2.0, Web 2.0 is a notion and denotes a platform for collective brainpower to use" (Huang \& Benyoucef, 2013)

Internet based medium of communication and human interaction refers to the collection of new means of social interaction and communication. In the same vein, Mayfield (2008) listed some of the features common to newest medium of communication and interrelationship. These features are: social media paves way for unrestricted public participation in the interactive session, it is open to all eligible members of society, and it enables participants to express their opinion, and strengthen or weaken inter-relationship among users.

The features itemized above, shows that these new medium of information dissemination and interaction has provided an avenue where Islamic religious scholars can explore their activities, to reach the audience which ordinarily with the orthodox mass media could not be possible or extensive to use. It has been observed that majority of scholars who explored the potentialities and effectiveness of web based means of communication and interaction were from the secular disciplines like Engineering, Computer Science and Social Sciences.

Islam dan social media

Hosseini \& Ramchahi (2014) has examined the role of information technology (web and internet) in preaching activities. The study's outcome indicated that information technology was able to support the transmission of knowledge about tajweed, hadith, tafseer, and another emerging subject. Not only that, the presence of information technology will enrich the user's perception of Islam. This is achieved through the utilization of the modern interactive and communication media for reading of current works and disseminating same to the world via these medium (Hosseini \& Ramchahi, 2014).

The use of blogs as one of the social media platforms for Islamic preaching in Malaysia has been examined by Adam, et al. (2014). That scholars adopted the new media blog to share Islamic awareness. In addition, this has also been regarded as one of the most successful alternative methods of disseminating all Islamicrelated knowledge. In spite of that, among young Muslims, the use of the modern communication and interactive medium to search for information about the teachings of Islam is still poor. Mostly individual's uses the social media for entertainment and social activities with other people across the globe, they viewed the blog as media, not to find a specific information.

Similarly, Agboola (2014) reported that there is still little utilization of the social media technology for educative 
Da'wah. That this is because only a few individuals contribute to it usage for Islamic purposes. In addition, the new media users have increasingly been more drawn to social media rather than blogs. Therefore, it can be viewed as an alternative way to use social media in the Da'wah programmes. But Omar, et al. (2015) carried out a study on the impact of social media in the activities of da'wah in Malaysia. Throughout this study, it was concluded that in proselytising activities Islam, the use of social media is essential. The popularity of social media may be an alternate means of efficiently disseminating Islamic messages to people. In that way, intellectuals need to be able to use social media as an evangelizing medium.

Islamic subjects have been found in the past in cassette recordings, magazines, and leaflets available in libraries, Islamic institutions, and Masjid. Non-Muslims and Muslims cannot benefit from these resources unless they are near to them. Today, in serving and reporting the teachings of Islam around the globe, Muslims have recognized and are utilizing social media as one of the tool of information technology (Adam \& Salim, 2009).

Several activities on various Islamic topics (Qur'an, Hadith, Sunnah, Tafseer, Seerah, Fiqh, Translation, etc.) became accessible on the social media technological platforms in various forms (audio, video, text, etc.). In the modern time, the new interactive and communicating medium the social media have become the most commonly used media in the dissemination of the true message of Islam. In various countries around the world, millions of Muslims and non-Muslims use social networking sites to hold online discussions on various issues affecting the Muslim Ummah. Islam is present all the time on all of these social interactive and communication platforms. This reflects the social behaviour of people in general and Muslims in particular (Ashraf, 2010).

Ibahrine (2014) conducted an empirical study on how social media aided the spread of the teachings of Islam. The researchers sampled social media handlers and users and examined the correlation between the level of social media usage and engagement in Islam related activities. The study found that there is positive correlation between the level of social media usage and its influence on user's Islamic routine activities. The study further established that adolescents among Muslims used the social media to dodge from the public view and control of parents through virtual interactions with friends and illicit activities which are against the tenants of Islam. The absence of control over social media sites has become a contested domain, because it has opened an avenue for the uneducated people to present themselves as scholars. Allievi (2002) lay claim to the term 'neo-communities' to refer to the emerging Muslim community in Europe that has started to assume an underlying authority manifested in the political opinions toward the foreign policy concerning Muslim countries. His work is an strive to research the position of the internet and the mass media in building transnational and non-ethnic Muslim groups focusing at the strategies involved in the manner they set up their borders in addition to trans-borders. Allievi gave examples of Islamic networks that underwrote the construction of Muslim neo-communities 
in Europe and fostering a brand new image of Islam.

An area where Islam benefits from the potentials of web based means of communication is through proselytization. This is a method of spreading the Words of Allah mainly by the learned Islamic scholars and students of knowledge. Similarly, in some countries, there are social media pages created by students, friends and associates of deceased Islamic scholars in order to disseminate their works and teaching for the benefit of Muslim community and preserved knowledge for the younger generations. It has been observed that adaptation of social media as a medium of proselytization is not exclusive to religious leaders.

Not only that, Muslim scholars and their followers also tweet verses of the Glorious Qur'an and Ahadith of Prophet (May the salutation and benediction of Allah be upon him). The propagation of religious info frequently reaches its zenith during the 'fasting Ramadan', when Muslims are inwardly and superficially encouraged to manage and process religious messages in form of tweets. This new phenomenon brought some changes in the way the Islamic faith is promoted amongst Muslim devotees and non-Muslims alike. Also, during Hajj events, usually some pilgrims do tweet and add photographs and video clips posing their sense of virtual spirituality to their relatives. These practices contribute to the enhancement of spirituality and copiety of the Islamic Ummah (Mohammed, 2014).

Entirely these indicate that the various means of social communication in the contemporary age can also be incorporated in the custom of the diffusion message of Allah and safeguarding Islam from the opposition of critics outside the Islamic fold. Furthermore, this new medium of social interaction and communication also fashioned an Islamic popular diplomacy, which also involves the worldwide mobilization of Muslim believers via digital platforms, in case of individual or group attacks on the Glorious Qur'an or the person Prophet Muhammad. Notable examples are the motion pictures of a pastor in America who plans to burn copies of the Noble Qur'an in year 2010 and also the 'Innocence of Muslims' an anti-Islam clip (Mohammed, 2014). However, this new media has also unfolded the leeway, particularly for the younger Muslims, to communicate and interact with their religion and friends in a manner which their parents could never imagined. When the Ummah became a spiritual notion, with Muslim Ummah divided by region, country and tribe, the new media technology has shattered obstacles and allowed young Muslims to stay connected with their religion and friends regardless of where they come from. It permits them to communicates, and speak about what it takes to be a Muslim in the 21 st century, particularly for the Muslims residing in the Western world (Mohammed, 2014).

The world of social media and muslim scholars

During this first wave period, Muslim scholars were genuinely considered descendants of the Prophet Muhammad (may Allah's peace and 
benedictions be upon him). The transformation of religious education between Muslim scholars and their followers through formal education institutions took place directly in reflective and interactive ways. Terminologically speaking, individuals that are especially interested in pursuing religious knowledge are referred to as the Ummah, whereas those who pursue religion, in general, are referred to as the students of knowledge. The difference between the two is not restricted by the media's distance or mediation, but by their religious understanding (Iswandi, 2018).

The second phase of connections between Muslim scholars and the public took place through conventional mass media-assisted mediation, among other print media, including newspapers or magazines, and broadcast media, such as television and radio. Hent de Vries (2001), a Dutch thinker, has already provided such an interpretation, arguing that religion has been unable to achieve self-actualization without mediation and debate. However for Hoover (2010), emphases his observations on the influence of religion and its success on cultural commodities and artifacts. According Peters (2010) that, the relationship between religion (in this case with religious scholars) and the mainstream media reveals that both have a fundamental relationship that suggests the basis of potential religious appearance.

A fascinating subject of debate has been the relationship between faith, religious experts, and the media, making it more difficult to discuss religion without discussing the media. Hoover (2010) notes that it seems that spirituality and the media are more intertwined. It is exceedingly difficult to present religion as being uninfluenced by the media in terms of theories and activities in the twenty-first century. Though religion and the media are radically separate domains, their boundaries have recently become more distinct. It's more complex. In the cases observed, new manifestations of religiousness and culture are generally linked to the existence of new media. In the third wave, social media material is the key subject of social media conversation as a distributor reflecting religion through different means.

Helland (2002) suggests that there are digital religious contexts in which individual religious perceptions and understandings are synonymous in the age of internet-based religious practices. The disparity in the definition of 'online religion' (religious knowledge on the internet) and 'religion online' (religious views and activities on the internet) is therefore one of the most significant factors emerging in the recent era of digital media (Cowan, 2004; Young 2004; Helland, 2000). Computer Mediated Communication have facilitated or controlled religious practices that have identified cyberspace as an important place for performing rituals and as a source of strength for offline religious believers (Berger \& Ezzy, 2004). Social media, however, has been found to be hired by Muslim scholars as a new technological network, consisting of Facebook, WhatsApp, YouTube, Twitter, Telegram, etc., as a medium to offer religious sermons or teachings. Not only that, several Muslim scholars have regarded social media as an instrument that can be used for various 
constructive social interaction (Iswandi, 2018).

\section{Result and discussion}

This section relates the results and discussion of the paper and below are the results and discussion as contained under the various subheadings.

\section{Social Networking Learning}

Opportunities for Muslim Scholars

In terms of the new media tool, there are many resources and its use on social media which can be employ Muslim scholars must, in particular, be used to spread the message of Islam to Muslims and non-Muslims across the globe. It is a common reality that today's social media has the power to shift the religiosity and habits of piety of the Ummah.

\section{Disseminating Islamic Da'wah}

The Sahabah (may Allah be pleased with them) and other Muslims used to travel on horseback or use other native transport during the earliest time of Islam in order to attain or spread the message of Islam to several other segments of the Arabia Peninsula. In this narrowed way of communication, people are not realistic and swift, but apart from the amazing grace of Allah, the growing influence of Islam has increased. In addition to this, the new media facilities in this viewpoint have given Islam more ground to explain the wider world more of the real teachings of Islam. Added to this, if these channels are properly used, Islam's frontier and its teachings in the minds of Muslims and non-Muslims will be strengthened and extended. Social media in the world today can be used to correct minds of non-believers on their perception of Islam (Qayyum \& Mahmood, 2015). In addition to this, the use of social media by Muslim scholars today is an opportunity for the Muslim world to portray the beauty and values of Islam via the modern medium of communication. The principles of Da'wah are mentioned in the Glorious Qur'an where Allah says:

Invite to the way of your Lord with wisdom and good instruction, and argue with them in a way that is best. Indeed, your Lord is most knowing of who has strayed from His way, and $\mathrm{He}$ is most knowing of who is (rightly) guided (Qur'an, Surah an-Nahl 16:125)

It is noteworthy that the message of Islam has been held with great respect and not restricted to any specific topic here. This involves all the invitation's means, avenues and materials. In view of the above verse, and for the sake of assertion of the period, it can be said that the age of the new technology can also be used in Islam. The Prophet (may Allah's peace and benedictions be upon him) said:

Convey (my teachings) to the people even if it were a only sentence, and tell other the stories of Banu Israel (which have been taught to you), for it is not sinful to do so. And who ever tells a lie on me intentionally, will surely take his place in the (Hell) Fire (Sahih AlBukhari, Volume. 4, Hadith Number. 667). 
As it is important for the use of the new medium of communication in the sense of Islam's invitation and Tablig in the contemporary period. Once Muslim scholars speak on social media sites about Islam and its elegance, it spreads quickly in moments to all corners of the world. Because of its broad reach and versatility, it is easy for social media to spread Islam's true message to the entire globe. Da'wah operations can be easily performed by sitting in the house via social media platforms. As a way to spread Islamic Da'wah, Shaykh Sani Rijiyar Lemu, Dr. Zakir Naik, Mufti Ismail Menk, Prof. Mansur Sokoto, Numan Ali Khan, Shaykh Musa Assadus Sunnah, Bilal Philips, and other better Muslim scholars use social media (ShanA-Alahi \& Huda, 2017). The Noble Prophet (Benedictions and peace of Allah be upon him) said:

Make things easy and do not make things difficult. Give glad tidings and do not repel people" (Sahih Al-Bukhari, Hadith 2873).

Muslim scholars can now sit at the ease of their homes and conveniently gather knowledge about Islam via social media and share the message with people.

Currently, the Glorious Qur'an, Hadith, reading and preserving different Islamic references, etc., have become much simpler through social media channels. It was usually difficult to compile the verses of the Qur'an or the Noble Prophet's Ahadith (peace and benedictions of Allah be upon him), but it has become faster and easier. These can be shifted from one Surah to another Surah easily. The modern media technology, through one its channel blog may perhaps be used for religious reasons as one medium to reach out the public. You can write important messages about the religion of Islam via this blog and, at the same time, post information on Facebook, YouTube and other sites through this modern means of communication referred to as blog.

Similarly, the services of these modern communication channels can be employed to engage and communicate with the Muslims faithful's and nonMuslims with the aim of spreading the true teachings of Islam and winning hearts via the proper utilization of the tool in Da'wah which is a crucial commitment for every sundry Muslim scholar and Islamic leaders. Currently, this new media technology has come to be an invaluable means to pursue the path of spreading and the dissemination of the Islamic ideals and thoughts (Mohammed, 2014).

The communication power of the social media offers an enormous chance for the Muslim community to gain the public views and understanding of the message of Islam. The Muslim Ummah need to stop attitudes of our self as community that cannot create a disparity; Muslims most utilize social media networking technology as medium of communication and upload our voices to the majority of the Ummah (Abdul and Zaid, 2015).

Islam and Learning Opportunities on Social Media

In Islamic history, the pursuit of knowledge about Islam was generally governed by the Masajids, educational institutions, and scholarly knowledge. Such traditional learning options remain 
essential. Muslim scholars and Muslims are also able to teach and research, challenge, inform, and exercise Islamic Da'wah via social media platforms in modern times. There are many more possibilities for Muslim scholars to study Islam and its teachings and spray insight on them. Muslims and non-Muslims, for example, can listen to and watch lectures by Muslim scholars from various regions of the globe in several languages at any time on YouTube, Facebook, and Twitter.

It has presently been observed that, the modern media channels have the power to accommodate learning devices which could also be of benefit to the Islam and the Muslim world. This social media communication tools can be employ by scholars of the Islamic faith to render lectures and programmes to the Muslim community either via recorded videos or live-stream.

\section{Countering the Orientalists}

Modern media technology, the social media are valuable outlets that are useful and can be utilized to correct and address the ideas of Orientalists against Islam by religious clerics. Muslim scholars and other educated Muslims are capable putting bring things in the right direction by correcting the numerous social media posts that dent the Islamic image and depict Muslims as terrorists.

The researchers similarly observed that owing to the flexibility of the new medium of interaction and communication, is an opportunity for the Muslim religious clerics to exploit these channels of communication in portraying the true message and teachings of Islam as contained in the Noble Qur'an and Sunnah of Prophet Muhammad (May the peace and benedictions of Allah be upon him). There are Fatwah on social media with a lot of misconceptions on the teachings Prophet Muhammad (May the peace and benedictions of Allah be upon him) that need to be put in it right perspective by Islamic religious scholars.

\section{Muslim Clerics and Challenges of Social} Media

In terms of social media, one of the biggest issues Muslim scholars are currently facing, and probably one of the most challenging problems, is the absence of spiritual nurturing.

The researchers have observed that some users of social media have not actually graduated from a formal Islamic learning institution, nor have they participated in any organized Islamic science learning program and however frequently try to offer rulings on certain Islamic issues that use to create conflicts among the Muslim Ummah. This further aggravates the issue facing Muslim scholars when it comes to the dissemination and offering of Fatwa via social media channels as a new means of interaction with the Muslim community around the world.

\section{Proliferation of Unlearned Scholars}

The researchers have observed that in the realm of the modern media domain currently, is the complete opposite to the process of followership and education preceding leadership. Anonymous and unqualified persons who have no connection to any kind to Islam, hence due to the large followers on the contemporary means of interaction and communication. This individuals have made up pages or channels on various fields of Islam on these social media 
networking sites which provide them with the avenue to post, share, upload and issue out their thoughts and ideas which goes against the true message of the religion of Islam. This sets of unlearned scholars attained this by the usage of argument, contradictions, and rejoinder through visual means, discussing their disputatious beliefs or complexities, which also includes different methods of capturing the attention of the public. Platforms developed by these individuals on the modern communication channels and the sort of messages it carried has given them fame to garner outsized number of subscribers and fans, thereby justifies their work in the presence of their admirers and subscribers.

\section{Distortion of facts about Religions}

In the face of the usage of the social media as a modern means of communication and interaction, fabricated materials and messages were frequently disseminated about Islam and with this, efforts were made to create turmoil amongst people of various religions in different locations around the world. This group individuals make maximum usage of the new media technology such as YouTube, Facebook, Telegram, Twitter, Zoom, WhatsApp, etc. to instil fear and makeup fake reports. The message on the modern media as mode of interactions and communications in the media currently do go against good of Islam and Muslims. The Muslim and the encounter in the media of the western world is usually on the portrayal of the image of Islam and Muslims. There are channels new media that are dedicated for disseminating false and bogus information and messages on the religion of Islam, Muslim clerics, leaders and times fallacies about Muslims. The community of nonbelievers living in such manner perceives Muslims as traitors and extremists. Usually, undesirable impacts on modern medium of interaction the social networks are much however, it cannot be mere the part the Muslims and Islam plays as a religion, then also an advantage (Nasr, 2005).

\section{Diversion from Allah's Message}

Whereas a significant amount of Muslim work is conducted on social media, for the vast number, it remains a distraction. Social media is indeed a diversion that Muslim scholars and leaders are often taken away from performing their religious activities and family obligations as well as other duties. This modern social interacting medium can also take one away from integrating, meeting and helping the people in their locality. It takes an individual away from the reflecting on the Glorious Qur'an, and from other positive good deeds, as the researchers have observed. Perhaps so much time is consumed listening to various programs, and sometimes much more time is wasted tweeting and updating on the various social channels of interaction. As Muslims, we need to use social channels of interaction and communication to convey the message of the Noble Prophet Muhammad (May the peace and benedictions of Allah be upon him) as contained in the Glorious Qur'an and his Ahadith (Abdul Hamid, 2015). Let it not be that Muslims allowed Shaytaan deceives us through what is contained therein the contemporary medium of communication and interaction and misleads us into thinking 
it is goodie we waste our time and resources for.

\section{Armed Groups and Extremists}

The use of social media for the purposes of Islamic Da'wah by armed groups and extremists is one of the major challenges for confronting Muslim intellectuals currently. Armed groups and extremists have been found of utilizing social channels of interaction and communication as a forum for recruiting and indoctrinating their teachings in the minds of Muslims against the true teachings of the Holy Prophet Muhammad (peace and benedictions of Allah be upon him). This also challenges the attempts made by Muslim clerics to reach out to the populace through social media channels of interaction in order to disseminate the message of the Prophet (May Allah's peace and benedictions be upon him) which were contained in the Noble Qur'an and his Sunnah. This presented Muslim scholars with a challenge because they use this forum to distract Muslim attention, create mistrust and cause havoc amongst Muslim Ummah.

Censoring of Da'wah Activities via Social Media

Social media versatility and lack of censorship have played a key role in the challenge faced by Muslim scholars in terms of using social media to spread the teachings of Islam. To some degree, lack of regulation has given space for incompetent clerics to present Da'wah and offer Fatwah through this modern interactive channels, which also poses serious challenges to scholars. In conventional mass media, control and censorship of messages and media content is a well-known practice. Online social interaction sites, however, have made this regulation virtually impossible as individuals from the comfort homes initiate messages and deliver them to the world without regard to any legislation.

\section{Conclusion}

The way Muslim scholars communicate and interact has been changed through their contact between computers or mobile devices linked through the internet services, which enable them to propagate the true teachings of Islam effectively to their audience. The services of the modern media channels has given users the right, without any censorship, to create their content and share it with the world. The freedom of thought granted by social media has simplified how religious clerics without face-to-face interaction disseminate messages to their audience. The absence of censorship provided by the porous cyber environment, however, has created an outlet for the propagation of uncorroborated verses from the Glorious Qur'an and Ahadith of the Prophet which also includes unverified messages attached to Islam. Most social networking sites were already saturated with arm chair researchers and overnight scholars who only copy and paste texts without verification from the original sources. Therefore, from the viewpoint of Islam, social media has been a doubleedged sword, depending on the way it is used, it has come with benefits and drawbacks. The lack of cyber space control is now becoming a threat, as the emergence of cyber-Islamic scholars is growing. In most cases, messages from these cyber scholars were deceptive, false 
and capable of igniting disputes between Muslims and non-Muslims in Nigeria and other parts of the world.

\section{Reference}

Hamid, A.I.S. (2015). The scholars and social media, Need for reflection. Khanqah Akhtari: Azaadville.

Abdul, Q., \& Zaid, M., (2015). 'Role of Social Media in the Light of Islamic Teaching'. Al-Qalam, 6(4): 27-36.

Adam, F., Anuar, M.M, \& Ali, A.H., (2014). 'The use of blog as a medium of Islamic da'wah'. Malaysia International Journal of Sustainable Human Development, 9(3): 74-80.

Adam, G., \& Salem, H., (2009). 'The impact of Facebook on our Muslims students'. Teach. Lib, 36(5): 36-52.

Agboola, A.K., (2014). 'Religious communication and internet usage: How do Muslims fare on the web?' Middle-East Journal of Scientific Research, 8(1): 11-20.

Al-Hilali, M.T. \& Khan, M.M. (2006). Translation of the meanings of the Noble Qur'an in

Allievi, S., (2002). Islam in the public space. In S. Allievi, \& J. Neilsen (Eds.), Muslim networks and transnational communities in and across Europe (pp. 1-27). Leiden, NLD: Brill Academic Publishers.

Ashraf, M., (2010). 'The role of information technology in Islam'. Canadian Journal on Network \& Information Security, 1(7): 98-122.
Aznan, Z.S. (2012). Islamic values for ICT development with reference to Malaysia context. (Unpublished doctoral thesis). Faculty of Science, University of Malaya.

Bandura, A. (1986). Social Foundations of Thought and Action. Englewood Cliffs, NJ.

Berger, H. A. \& Ezzy, D. (2004). The internet as virtual spiritual community: Teen witches in the United States and Australia. In L. L. Dawson \& D. E. Cowan (Eds.), Religion online: Finding faith on the Internet (pp. 67-90). New York: Routledge.

Cowan, D. E. (2004). Contested spaces: movement, countermovement, and espace propaganda. In L. L. Dawson \& D. E. Cowan (Eds.), Religion online: finding faith on the internet (pp. 4366). New York: Routledge.

Glaser, B. (1963). 'The use of secondary analysis by the independent researcher'. The American Behavioral Scientists 6: 11-14.

Habib, N.I., (2018). The Importance of Social Media and its Side Effects, Daily Jugantor. Retrieved from https://www.jugantor.com/todayspaper/subeditorial/116774/.

Heaton, J. (2004). Reworking qualitative data. London: Sage Publications.

Helland, C., (2000). 'Surveying for salvation'. Religion, 32(4): 293-302.

Helland, C. (2002). Online religion/religion online and virtual communities. In J. K. Hadden \& D. E. 
Cowan (Eds.), Religion on the internet: Research prospects and promises. London: JAI Press.

Hinds, P.S., Vogel, R.J \& Clarke-Steffen, L. (1997). 'The possibilities and pitfalls of doing a secondary analysis of a qualitative dataset'. Qualitative Health Research 7(3): 408-424.

Hoover, S. (2010). Religion in the media age. London and New York: Routledge.

Hosseini, S.E., \& Ramchahi, A.A., (2014). 'The impact of information technology on Islamic behaviour'. Journal of Multidisciplinary Engineering Science and Technology (JMEST), (1)5: 135-41.

Huang, Z., \& Benyoucef, M., (2013). 'User-centered investigation of social commerce design'. Paper presented at the International Conference on Online Communities and Social Computing.

Ibahrine, M., (2014). Islam and Social Media. In K. Harvey (Ed.), Encyclopedia of social media and politics (9: pp. 737-741). Thousand Oaks, CA: SAGE Publications. http://dx.doi.org/10.4135/978145224 4723.n299

Iswandi, S., (2018). 'New media, new relations: Cyberstalking on social media in the interaction of Muslim scholars and the public in West Sumatra'. Indonesia. Jurnal Komunikasi: Malaysian Journal of Communication. 34(1): 153-169. https://doi.org/10.17576/JKMJC2018-3401-09
Jusoh, N.H., \& Kamaruzaman, J., (2009). 'Using multimedia in teaching Islamic studies'. Journal Media and Communication Studies, 1(5) 086094.

Mayfield, A. (2008). What is social media? Download from http://www.icrossing.com/uk/ideas/fil eadmin/uploads/ebooks/what_is_soci al_media_icrossing_ebook.pdf.

Mohammed, I. (2014). Islam and social media. Download from https://blogs.lse.ac.uk/mec/2014/10/2 8/islam-and-social-media/

Khan, M.M. (1997). The translation of the meaning of Sahih Al-Bukhari (Arabic-English). Riyadh: Dar-UsSalam Publications.

Nations, D. (2019). What is social media? Download from https://www.lifewire.com/what-issocial-media-explaining-the-bigtrend-3486616.

Omar, F.I, Hassan, N.A, \& Sallehuddin, I.S., (2014). 'Role of social media in disseminating Dakwah Islamic perspectives relating to business, arts, culture and communication'. Proceedings of the 1st ICIBACC, 4358. https://doi.10.1007/978-981-287429-0_5.

Peters, J.D. (2010). Speaking into the air: A history of the idea of communication. Chicago: University of Chicago Press.

Saidin, A.Z., (2012). 'Maqasid syariah dalam ICT'. Solusi 45: 53-56. 
Sanusi, R.B., Gambo I.A., \& Bashir H., (2014). 'Use of social media among students of Nigerian Polytechnic'. International Conference on communication, media technology and design, Istanbul, Turkey, $24-26$ April.

Saifuddeen, S.M. \& Salleh, S.M. (2003). Strengthening dakwah with technology. Download from http://www.ikim.gov.my/index.php/m s/new-strait-times/6901strengthening-dakwah-withtechnology.

Vries, H.D. (2001). In media res: Global religion, public spheres, and the task of contemporary comparative religious studies. In Vries, H.de \& Weber, S. (Eds.), Religion and media. Stanford, CA: Stanford University Press.

Young, G. (2004). Reading and praying online: The continuity of religion online and online religion in internet Christianity. In L. L. Dawson \& D. Cowan (Eds.), Religion online: Finding faith on the Internet. New York: Routledge. 
This page intentionally left blank. 